\title{
Abundance and production of particle-associated bacteria and their role in a mangrove-dominated estuary
}

\author{
Maria Judith Gonsalves*, Shanta Nair, P. A. Loka Bharathi, D. Chandramohan \\ Microbiology Laboratory, National Institute of Oceanography, Goa 403-004, India, and Council of Scientific and \\ Industrial Research, India
}

\begin{abstract}
A 1 yr study was carried out in the mangrove-dominated, tropical Mandovi estuary (Goa, India) to assess the contribution of particle-associated bacteria (PAB) to the system's variability in terms of abundance and productivity. The suspended load, which was composed of inorganic mineral grains and allochthonous materials including mangrove litter, was high during the southwest (SW) monsoon season. The ratio of organic:inorganic content of these particles was low during the pre- and post-monsoon seasons. PAB abundance ranged from $0.01 \times 10^{10}$ to $22.8 \times 10^{10} \mathrm{~m}^{-2}$ and accounted for 4 to $94 \%$ of the total bacterial abundance. The variation in PAB abundance was due to their preferential colonization, which depended on the quantity and quality of the particles. The average annual PAB production was $214 \mu \mathrm{g} \mathrm{C} \mathrm{m}^{-2} \mathrm{~d}^{-1}$ and contributed to an average of $35 \%$ of the total bacterial production. Primary productivity (PP) was 137,14 , and $163 \mu \mathrm{g} \mathrm{C} \mathrm{m}^{-2} \mathrm{~d}^{-1}$ for the pre-monsoon, SW monsoon, and post-monsoon periods, respectively. The calculated maximum bacterial carbon demand (BCD) of PAB was $37 \%$ of the total BCD. On an annual basis, $<1 \%$ of PP contributed to PAB-BCD. It is suggested that the rest of the $\mathrm{BCD}$ was met from mangrove litter and other allochthonous sources. Principal component analysis showed that biotic parameters were predictors for $\sim 50 \%$ of the variability and had a marked seasonality linked to salinity. The allochthonous sources contributed significantly to the structure of the biological community of this mangrove-dominated estuary.
\end{abstract}

KEY WORDS: Particle-associated bacteria $\cdot$ Abundance $\cdot$ Production $\cdot$ Tropical mangrove estuary Goa $\cdot$ India

\section{INTRODUCTION}

Estuaries are the most dynamic and biologically productive ecosystems on earth (Schlesinger 1997). Biological processes in estuaries respond to changes in the quality and quantity of environmental inputs due to fluvial influence (Hubertz \& Cahoon 1999, Russell et al. 2006). Autochthonous production as well as imported organic and inorganic particles bring about variation in the autotrophic and/or heterotrophic nature of the estuary (De Souza et al. 2003, Ram et al. 2003, Russell \& Montagna 2007). Bacteria attached to these particles form an important constituent of the planktonic food web as they aggregate smaller particles and break down larger ones (Gorsky et al. 2000), and thus play a significant role in the mobilization of carbon. Activities of these associated bacteria play a major role regulating the biogeochemical fate of particulate organic matter (Crump et al. 1998, Crump \& Baross 2000). During the residence time of the particles, particle-associated bacteria (PAB) may show high enzymatic activities (Smith et al. 1992, Crump et al. 1998, Crump \& Baross 2000), decompose recalcitrant particles, and improve the nutritional quality of the particles. Thus estuaries serve as important sites for the bacterial degradation of terrestrial and riverine organic matter associated with particles (Lee \& Wakeham 1988). While PAB of temperate estuaries have been fairly well studied (Crump 
et al. 1998, Revilla et al. 2000), the data from tropical (Bano et al. 1997, De Souza et al. 2003) and sub-tropical (Ducklow \& Shiah 1993) estuaries are scant despite PAB being ubiquitous. In the Indus River delta, Bano et al. (1997) reported that bacterial production associated with particles was carbon limited and could have a major impact on mangrove ecosystem structure and functioning and the production of economically important fishes and shrimps. A study from the tropical Zuari estuary situated on the west coast of India showed that $\mathrm{PAB}$ are a significant component of the total bacterioplankton, and the dynamics were determined by the availability of the substrates and the re-suspension of the sedimented material (De Souza et al. 2003). Although adjacent to each other on the west coast of India, the Mandovi and Zuari estuaries are influenced by different factors, viz. a narrower channel, more freshwater input, and frequent navigation activities in the Mandovi than in the Zuari estuary. Thus, each estuarine environment exhibits a wide variation in its physical and chemical factors. One may expect PAB to be governed by different factors in each estuary. Even less understood is how monsoon-driven wind influences bacterial processes in a tropical estuary such as the Mandovi.

The Mandovi estuary, located in Goa on the west coast of India, is fringed with extensive mangroves and opens into the Arabian Sea. The average density of mangroves in the Mandovi estuary is 461 trees $\mathrm{ha}^{-1}$, and the litter yield in the Mandovi-Zuari estuarine system has been estimated to be $10.2 \mathrm{t} \mathrm{ha}^{-1} \mathrm{yr}^{-1}$ (Wafar et al. 1997). A high runoff of relatively easily degradable organic matter and recalcitrant matter from the leaf litter and inorganic particles from terrestrial regions comes into the estuarine system during the southwest (SW) monsoon season. This input of litter may be retained in the estuary either by sinking or re-suspension (Crump et al. 1998). Thus, the Mandovi estuary receives autochthonous and large allochthonous inputs from different sources, i.e. riverine discharge (particulate and dissolved matter) and mangrove leachate. Wafar et al. (1997) estimated particulate and dissolved organic carbon to be 498 and $876 \mathrm{mg} \mathrm{C} \mathrm{m}^{-2} \mathrm{~d}^{-1}$, respectively, in this estuarine system. The dissolved organic nitrogen and phosphorus released from the mangrove litter sustains the nutrient budget of the Mandovi-Zuari estuarine system (Wafar et al. 1997). The questions to be addressed in this context are: do bacteria colonize these particles and contribute to the nutrient budget and do these particles satisfy the bacterial carbon demand? To answer these questions, we estimated the abundance and production of PAB along with other biotic and abiotic factors that could be responsible for causing variations in the estuary.

\section{MATERIALS AND METHODS}

Study site. The average water column depth of the Mandovi estuary is $\sim 4 \mathrm{~m}$. It is influenced by tidal currents and is characterized by mixed semi-diurnal tides. The speed of propagation of both diurnal and semidiurnal tides is about $6 \mathrm{~m} \mathrm{~s}^{-1}$, which remains unchanged over a distance of $40 \mathrm{~km}$ from the mouth (Shetye et al. 1995). The maximum current velocity during a tidal cycle is $1.1 \mathrm{~m} \mathrm{~s}^{-1}$ (V. Sanil Kumar pers. comm.). The estuary is classified as a macrotidal estuary with spring tides $>2 \mathrm{~m}$ (Shetye et al. 2007). It is under the influence of the monsoon circulation and experiences annual recurrence of spells of heavy precipitation and is thus referred to as a 'monsoonal' estuary. The estuary has a relatively low run off-season during November to May compared to the heavy runoff period from June to October (Shetye et al. 1995). On an average, the volume of freshwater flowing through the Mandovi in a year exceeds the volume of the estuary by a factor of 40 . Over $95 \%$ of the freshwater efflux occurs during June to October, implying that the water in the river channel is flushed out and renewed several times. Such flushing makes the estuarine water become limnetic from head to mouth (Shetye et al. 2007) during the monsoon period. The well-defined seasons, viz. pre-monsoon (February to May), SW monsoon (June to September), and post-monsoon (October to January), bring about a marked variation in the biology of the system.

Sampling. The sampling station at $15^{\circ} 30.323^{\prime} \mathrm{N}$ and $73^{\circ} 52.430^{\prime} \mathrm{E}$ was located $\sim 12 \mathrm{~km}$ from the mouth in the lower reaches of the estuary (Fig. 1). Monthly collection was done for $1 \mathrm{yr}$ during slack water. Surface and near-bottom water samples were collected using a Niskin sampler and then transferred to acid-cleaned polypropylene bottles and processed in the laboratory within $2 \mathrm{~h}$ of sampling. For PAB parameters, the difference between total and free-living bacterial parameters was considered. For total bacterial parameters

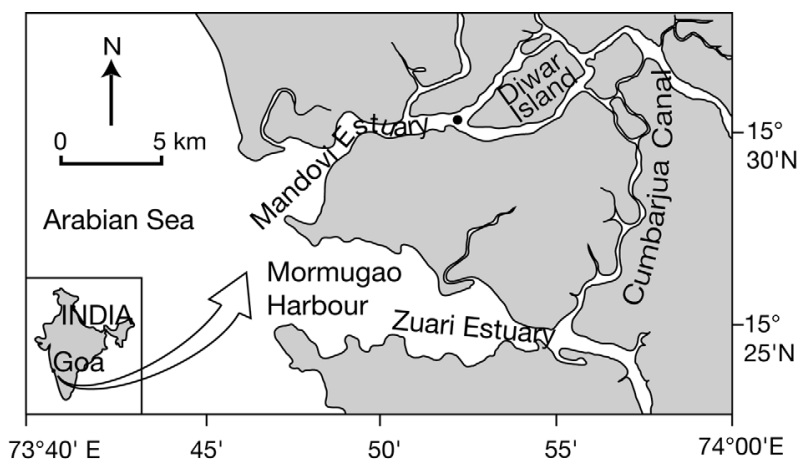

Fig. 1. Sampling site in the Mandovi estuary on the west coast of India 
(total bacterial abundance, TBA), we used water filtered through $220 \mu \mathrm{m}$ mesh. To estimate free-living bacterial parameters, we used water filtered through a $3 \mu \mathrm{m}$ pore size filter. To avoid clogging, especially during the monsoon season when the water was highly turbid, the filter papers were changed or the volume of water filtered was reduced, depending on the extent of turbidity (visual observation or slow filtration). To minimize cell damage and the possibility of forcing some large cells through the filter pores, filtration was done at very low vacuum $(<1 \mathrm{kPa})$.

Physico-chemical parameters. Water temperature was recorded, and $\mathrm{pH}$ (Orion 3 star) and salinity (Autosal 8400 A) were measured. Particulate organic carbon (POC) and particulate organic nitrogen (PON) were determined using a Perkin Elmer Elemental CHN analyzer (Model 2400). The water samples were filtered through a GF/D (Whatman) filter, dried at $60^{\circ} \mathrm{C}$, and fumed with concentrated $\mathrm{HCl}$ for $24 \mathrm{~h}$ to remove carbonates prior to $\mathrm{POC}$ and $\mathrm{PON}$ analyses (Hedges \& Stern 1984).

Particle parameters. The total number of particles present in the water sample was counted using a Coulter counter (TAIL Model), and the number was expressed volumetrically. Dry weight of $3 \mu \mathrm{m}$ particles was estimated gravimetrically. Water samples were filtered through pre-weighed $3 \mu \mathrm{m}$ pore size polycarbonate filters (Millipore) under low vacuum $(<1 \mathrm{kPa})$. The filters were then rinsed with $200 \mathrm{ml}$ of membranefiltered $(0.22 \mu \mathrm{m})$ distilled water, dried to constant weight at $40^{\circ} \mathrm{C}$ and weighed using a Metler balance (Model AE200), and expressed as a percentage of the total weight of particles $(0.22 \mu \mathrm{m}$ filter $)$. For blanks, only $0.22 \mu \mathrm{m}$ membrane filtered seawater was used. Suspended particulate matter (SPM) was determined gravimetrically on pre-weighed GF/D (Whatman) filters as described by Krey (1964). Filters that were used for SPM were then ignited at $450^{\circ} \mathrm{C}$ for $3 \mathrm{~h}$ and reweighed after cooling in order to determine the inorganic content of particles. The organic content was calculated by subtracting inorganic content values from SPM based on the loss on ignition method (LOI). Heiri et al. (2001) and others have sought to reduce the variability inherent to LOI, and Barille-Boyer et al. (2003) stated the various factors to be considered when calculating particulate organic matter (POM) using the LOI method.

Primary production and chlorophyll (chl) a concentration. Primary production (PP) was measured by the ${ }^{14} \mathrm{C}$ assimilation method (Lohrenz et al. 1992). Water samples were collected in four $300 \mathrm{ml}$ polycarbonate bottles from each depth. One ampoule of $\mathrm{NaH}^{14} \mathrm{CO}_{3}$ (specific activity of $185 \mathrm{kBq}$, Board of Radiation and Isotope Technology, Mumbai) was added to each bottle. Three bottles were used for light and 1 for dark incubation. Incorporation of ${ }^{14} \mathrm{C}$ was determined by filtering $100 \mathrm{ml}$ of the sample from each bottle through $\mathrm{GF} / \mathrm{F}$ filters (Whatman). The filters were transferred to scintillation vials and exposed to $\mathrm{HCl}(0.5 \mathrm{~N})$ fumes in vial. Liquid scintillation cocktail $(5 \mathrm{ml})$ was added, and the radioactivity was measured in a Packard 2500 TR liquid scintillation counter. PP rate was calculated as mg C m${ }^{-3} \mathrm{~d}^{-1}$ (UNESCO 1994). Chl a concentrations were estimated with a Turner Designs fluorometer after filtration of $500 \mathrm{ml}$ of water sample on Whatman GF/F glass-fiber filters and extracted with $90 \%$ acetone following Parsons et al. (1984).

PAB abundance and bacterial production. Samples for bacterial abundance were fixed in $2 \%$ (final concentration) formaldehyde. Bacterial abundance was enumerated by the acridine orange direct count (AODC) method (Hobbie et al. 1977). Counting was done in triplicate with 20 fields counted for each sample, and bacterial numbers were expressed as numbers $\mathrm{l}^{-1}$.

$\mathrm{PAB}$ production (PABP) was estimated based on the difference between the whole water (total bacterial production, TBP) and the water filtrate after removing the 3 to $220 \mu \mathrm{m}$ fraction in order to avoid conditions that may reduce radiotracer exchange with the particles. Bacterial production (BP) was estimated by measuring the rate of [methyl- ${ }^{3} \mathrm{H}$ ] thymidine incorporation (Fuhrman \& Azam 1982) by bacterial cells. Water samples $(30 \mathrm{ml})$ were incubated for $1 \mathrm{~h}$ with ${ }^{3} \mathrm{H}$-thymidine (specific activity $=52 \mathrm{Ci} \mathrm{mM}^{-1}, \mathrm{BARC}$, Mumbai) at a final concentration of $10 \mathrm{nM}$. The reaction was terminated with $2 \%$ neutral buffered formalin. The samples were then filtered through $0.22 \mu \mathrm{m}$ polycarbonate filters (pre-soaked in 5\% TCA), extracted with cold 5\% TCA, and rinsed with ethanol. The dried filters were then placed in scintillation vials and filled with $3 \mathrm{ml}$ of dioxane-based scintillation cocktail (Sigma). The samples were then radio-assayed using a Packard 2500 TR liquid scintillation counter. Thymidine incorporation rates were converted to bacterial carbon production (BCP) by using a conversion factor of $2.0 \times 10^{18}$ cells produced per mole of thymidine incorporated (Iriberri et al. 1990) and a carbon conversion factor of $20 \mathrm{fg} \mathrm{C}$ cell $^{-1}$.

Data analysis. Prior to statistical analysis, the data were depth integrated. Spearman's correlation analyses was performed on the normalized data using the statistical package Statistica for Windows version 6 (Stat Soft Inc.) to assess the relationship between PAB abundance, production, and other environmental variables. Multivariate principal component analysis (PCA) was performed using PRIMER version 6 (Clarke $\&$ Warwick 1994). The variables were $\log (x+1)$ transformed to normalize the data before performing PCA. Only those variables with a load of $>0.1$ were considered. 


\section{RESULTS}

\section{Water column characteristics}

Abiotic variables

The range in abiotic variables for the 3 seasons is given in Table 1. Water temperature of the Mandovi estuary ranged from 26.0 to $33.0^{\circ} \mathrm{C}$. Salinity showed wide variation ranging from 0 (June) during the SW monsoon season to a high value of 36 (May) during the pre-monsoon season. Suspended load was recorded throughout the study period with a high load of $1.4 \mathrm{~g}$ $\mathrm{m}^{-2}$ during the SW monsoon season. The major component of the SPM was inorganic in nature and increased with increase in the quantity of SPM $(\mathrm{p}<0.001, \mathrm{r}=$ 0.94). These inorganic particles were mainly clay minerals like montmorillite, illite, kaolinite, chlorite, gibbsite, and goethite. Among these, kaolinite and chlorite were dominant and at times reached as high as $45 \%$ (data not shown). The annual variation in the POM: SPM ratio was between 0.02 and 0.77. Although the SPM showed seasonal variation, the particle number and the percentage of weight per volume of particles of sizes between $>3$ and $<220 \mu$ m did not show marked variability with season. The particle number ranged from 3.7 to $12.7 \times 10^{9} \mathrm{~m}^{-2}$, except in October,

Table 1. Range (mean) of water column characteristics in the Mandovi estuary. SPM: suspended particulate matter, POM: particulate organic matter, POC: particulate organic carbon, PON: particulate organic nitrogen

\begin{tabular}{|lccc|}
\hline \multirow{2}{*}{ Parameters } & \multicolumn{3}{c|}{ Monsoon season } \\
\cline { 2 - 4 } & Pre & SW & Post \\
\hline Temperature $\left({ }^{\circ} \mathrm{C}\right)$ & $29.5-33.0$ & $26.0-32.0$ & $28.0-32.5$ \\
& $(31.1)$ & $(28.3)$ & $(30.5)$ \\
$\mathrm{pH}$ & $5.9-7.9$ & $5.9-7.9$ & $6.1-8.1$ \\
& $(7.3)$ & $(6.9)$ & $(7.5)$ \\
Salinity & $29-36$ & $0-10$ & $17-31$ \\
& $(32.0)$ & $(4.0)$ & $(25.0)$ \\
SPM $\left(\mathrm{g} \mathrm{m}^{-2}\right)$ & $0.03-0.70$ & $0.62-2.53$ & $0.05-0.29$ \\
& $(0.22)$ & $(1.37)$ & $(0.19)$ \\
Inorganic $\left(\mathrm{g} \mathrm{m}{ }^{-2}\right)$ & $0.01-0.69$ & $0.57-2.46$ & $0.02-0.26$ \\
& $(0.21)$ & $(1.33)$ & $(0.15)$ \\
POM:SPM & $0.03-0.77$ & $0.02-0.07$ & $0.11-0.70$ \\
& $(0.29)$ & $(0.04)$ & $(0.28)$ \\
Particle wt $(\%)$ & $44-64$ & $22-56$ & $37-70$ \\
& $(52)$ & $(42)$ & $(52)$ \\
Particle no. $\times 10^{9} \mathrm{~m}^{-2}$ & $5.1-12.7$ & $3.7-11.6$ & $6.5-137.0$ \\
& $(8.1)$ & $(6.3)$ & $(40.2)$ \\
POC $\left(\mathrm{mg} \mathrm{m}^{-2}\right)$ & $0.8-7.8$ & $2.6-17.9$ & $3.5-6.6$ \\
& $(3.3)$ & $(7.6)$ & $(5.3)$ \\
PON $\left(\mathrm{mg} \mathrm{m}^{-2}\right.$ ) & $0.2-1.6$ & $0.6-2.5$ & $0.2-1.3$ \\
& $(0.6)$ & $(1.3)$ & $(0.7)$ \\
POC:POM & $0.07-0.36$ & $0.04-0.40$ & $0.14-0.17$ \\
& $(0.17)$ & $(0.18)$ & $(0.16)$ \\
& & & \\
\hline
\end{tabular}

when it was $137 \times 10^{9} \mathrm{~m}^{-2}$. The percentage wt:vol of the $>3 \mu \mathrm{m}$ fraction during all the months ranged from $22 \%$ in June to $70 \%$ in December. On an annual basis, organic carbon of the particles ranged from 0.8 to $17.9 \mathrm{mg} \mathrm{m}^{-2}$, with the pre-monsoon month of March having the lowest and the monsoon month of August the highest value. Organic nitrogen content of particles showed monthly variation. The seasonal averages were $0.6,1.3$, and $0.7 \mathrm{mg} \mathrm{m}^{-2}$ during the pre-monsoon, SW monsoon, and post-monsoon, respectively. As in the case of organic carbon, organic nitrogen was high during the monsoon season. In general, the particle POC:PON ratio ranged from 4.5 to 7.4 during the premonsoon, 4 to 7.2 during the SW monsoon, and 4.4 to 18.1 during the post-monsoon season. PCA aggregated the above abiotic variables into the second (PC2) and third (PC3) component only. The variables were salinity, SPM, and inorganic content for PC2 and explained ca. $25 \%$ of the variation. In addition to the variables in PC2, PC3 included particle number and nature of the particle (POC and PON), which explained ca. $10 \%$ of the variability (Table 2 ).

Table 2. Principal component analysis of variables, showing eigenvectors (coefficients in the linear combinations of variables making up PCs). Values with a load of $>0.1$ are shown in bold. SPM: suspended particulate matter, POM: particulate organic matter, POC: particulate organic carbon, PON: particulate organic nitrogen, PP: primary productivity, TBA: total bacterial abundance, PABA: particle-associated bacterial abundance, TBP: total bacterial production, PABP: particle-associated bacterial production

\begin{tabular}{|lrcc|}
\hline PC & $\begin{array}{r}\text { Eigen- } \\
\text { values }\end{array}$ & $\begin{array}{c}\text { Variation } \\
(\%)\end{array}$ & $\begin{array}{c}\text { Cum. variation } \\
(\%)\end{array}$ \\
\hline 1 & 12.8 & 47.9 & 47.9 \\
2 & 6.81 & 25.5 & 73.4 \\
3 & 2.74 & 10.3 & 83.7 \\
Eigenvectors & & & \\
Variables & PC1 & PC2 & PC3 \\
\hline Salinity & -0.031 & $\mathbf{0 . 3 5 7}$ & $-\mathbf{0 . 3 1 1}$ \\
SPM & -0.049 & $-\mathbf{0 . 5 0 5}$ & $-\mathbf{0 . 2 7 7}$ \\
Organic & 0.001 & -0.071 & -0.056 \\
Inorganic & -0.037 & $-\mathbf{0 . 6 2 4}$ & $-\mathbf{0 . 4 0 1}$ \\
POM:SPM & 0.027 & 0.004 & -0.025 \\
Particle no. & -0.012 & 0.085 & $-\mathbf{0 . 1 1 5}$ \\
Particle wt. & 0.004 & 0.055 & 0.056 \\
POC & 0.046 & -0.061 & $\mathbf{0 . 1 1 4}$ \\
PON & 0.035 & -0.081 & $\mathbf{0 . 2 0 2}$ \\
POC:PON & 0.011 & 0.030 & -0.083 \\
Chl $a$ & -0.026 & $\mathbf{0 . 3 3 0}$ & $\mathbf{- 0 . 4 9 1}$ \\
PP & $\mathbf{0 . 1 0 7}$ & $\mathbf{0 . 2 8 6}$ & $\mathbf{- 0 . 3 9 1}$ \\
TBA & $\mathbf{0 . 2 6 2}$ & -0.061 & $-\mathbf{0 . 1 3 5}$ \\
PABA & $\mathbf{0 . 2 5 5}$ & -0.050 & $\mathbf{- 0 . 1 4 0}$ \\
TBP & $\mathbf{- 0 . 1 8 4}$ & 0.024 & $\mathbf{- 0 . 1 6 5}$ \\
PABP & $\mathbf{0 . 1 5 4}$ & -0.014 & $\mathbf{0 . 3 2 7}$ \\
POC:POM & $\mathbf{0 . 6 6 4}$ & 0.063 & $\mathbf{0 . 1 2 2}$ \\
\hline & & & \\
\hline
\end{tabular}




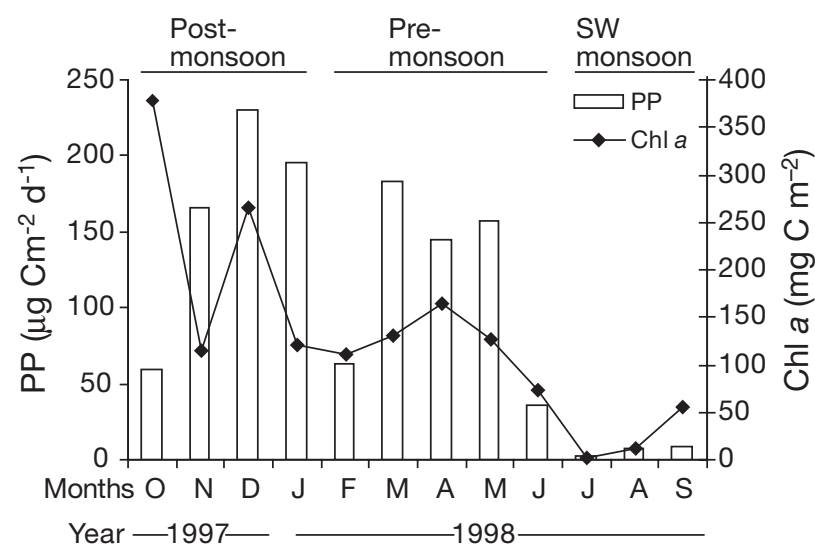

Fig. 2. Monthly variation in primary productivity and chl a

Biotic variables

Chl a ranged from 111 to $165 \mu \mathrm{g} \mathrm{C} \mathrm{m}^{-2}$ during the pre-monsoon, 1.8 to $74 \mu \mathrm{g} \mathrm{C} \mathrm{m}^{-2}$ during the monsoon, and 116 to $379 \mu \mathrm{g} \mathrm{C} \mathrm{m}{ }^{-2}$ during the post-monsoon season (Fig. 2). PP varied from a minimum of 62.5, 2.6, and $59.5 \mu \mathrm{g} \mathrm{C} \mathrm{m} \mathrm{C} \mathrm{d}^{-1}$ to a maximum of 183.1, 36.5, and $230.6 \mu \mathrm{g} \mathrm{C} \mathrm{m}^{-2} \mathrm{~d}^{-1}$ during the pre-monsoon, SW monsoon, and post-monsoon seasons, respectively (Fig. 2). The PP value was 137, 14, and $163 \mu \mathrm{g} \mathrm{C} \mathrm{m} \mathrm{C}^{-1}$ for the pre-monsoon, SW monsoon, and post-monsoon periods, respectively. PCA showed that PP was one of the variables in PC1. However, chl a was a component of PC2 (Table 2).

TBA was of an order of $10^{10} \mathrm{~m}^{-2}$. In the study site, it varied from 0.9 to $2.4 \times 10^{10} \mathrm{~m}^{-2}$ during the pre-monsoon, 0.08 to $9.2 \times 10^{10} \mathrm{~m}^{-2}$ during the SW monsoon, and 0.9 to $27.5 \times 10^{10} \mathrm{~m}^{-2}$ during the post-monsoon (Fig. 3). On an annual basis, the average particle-associated density accounted for $65 \%$ of the total bacterial community. The average PAB seasonal load was $1.1 \times$ $10^{10} \mathrm{~m}^{-2}, 3.5 \times 10^{10} \mathrm{~m}^{-2}$, and $8.2 \times 10^{10} \mathrm{~m}^{-2}$ during the pre-monsoon, monsoon, and post-monsoon seasons, respectively. The trend of the distribution of the PAB community was similar to that of the total community (Fig. 3). Likewise, when TBP increased, PABP also increased. Annually the total production ranged from 140 to $2280 \mu \mathrm{g} \mathrm{C} \mathrm{m}^{-2} \mathrm{~d}^{-1}$. The contribution of PABP to TBP varied from 13 to $79 \%$, and ranged from 66 to $863 \mu \mathrm{g} \mathrm{C} \mathrm{m} \mathrm{C}^{-1}$ (Fig. 4). The seasonal average of PABP was 137.3, 210.8, and $293.6 \mu \mathrm{g} \mathrm{C} \mathrm{m}^{-2} \mathrm{~d}^{-1}$ during the pre-monsoon, SW monsoon, and post-monsoon seasons, respectively. The ratios of PABP:PP were 1.0, 15.2, and 1.8 for the pre-monsoon, SW monsoon, and post-monsoon period, respectively. PCA showed that the biological components were responsible for $47.9 \%$ of the variability. Particle number and nature of the

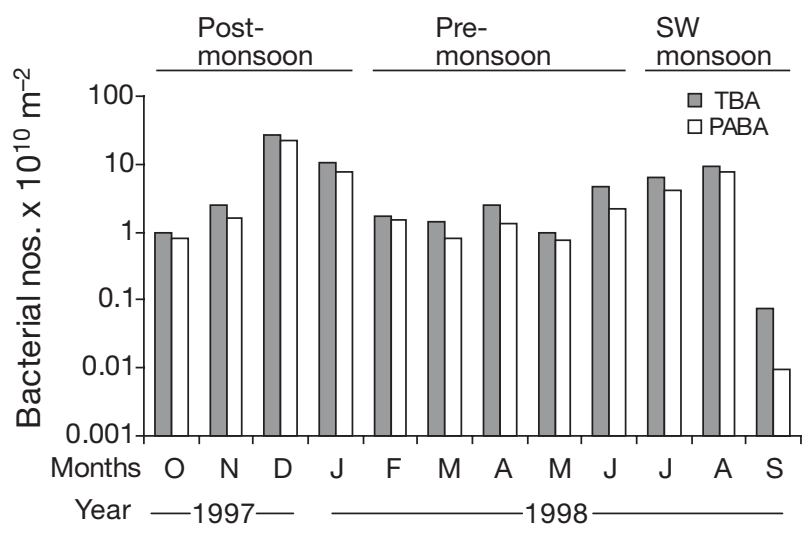

Fig. 3. Annual variation in the total bacterial (TBA) and particle-associated bacterial (PABA) abundance in the Mandovi estuary

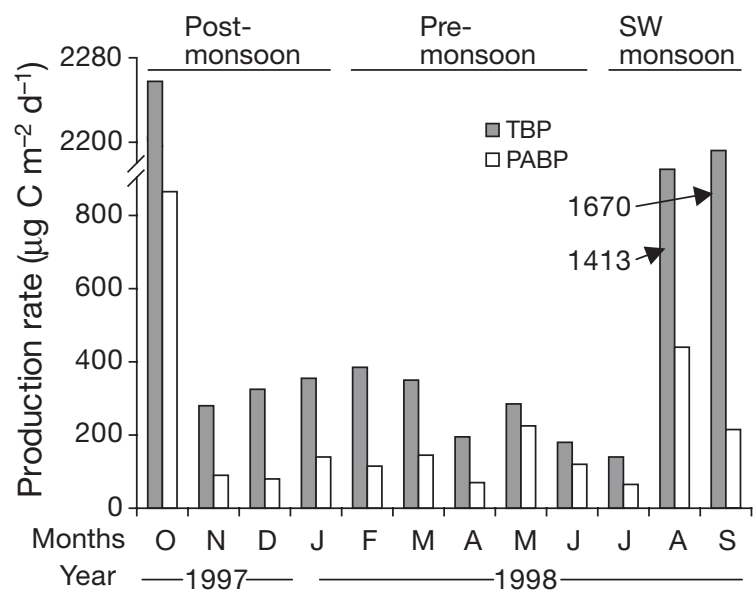

Fig. 4. Annual variation in the total bacterial production (TBP) and particle-associated bacterial production (PABP)

particle along with biological variables in PC3 accounted for about $83.7 \%$ of the variation (Table 2 ) in the estuary.

\section{DISCUSSION}

In an estuary, suspended matter determines the habitats and structure of the microbial community (Chen et al. 2005). The source, nature, and composition of the particles in the suspended matter affect the microbial processes. In the Mandovi estuary, the SPM and the particles ( $>3$ to $<220 \mu \mathrm{m}$ ) were dominated by inorganic fractions and showed seasonal variation. The quantity of SPM was twice that recorded in the adjacent Zuari estuary. Sixty percent of the latter particles were rich in organic carbon (De Souza et al. 2003), unlike those in Mandovi. Although the factors con- 
tributing to efflux of water to both the estuaries are similar, the nature of fluvial inputs and the watershed area determines the nature of the particles. A recent study on fluvial inputs into the Mandovi estuary (Mesquita \& Kaisary 2007) has shown that considerable inputs from anthropogenic activities, mainly in the form of dissolved/particulate manganese and iron are brought in by wind-borne transport during the non-monsoon months and by river runoff during the SW monsoon from mining rejects in the vicinity. This was reconfirmed in our study as the particles showed the presence of clay mineral grains like montmorillite, illite, kaolinite and chlorite, gibbsite, and goethite. This is further corroborated by the low POM:SPM ratios encountered in this study. The recalculated POM based on the method suggested by Barille-Boyer et al. (2003) did not bring about a significant change in the POM:SPM ratio. As suggested by Barille-Boyer et al. (2003), it is essential that a factor for this estuary is calculated and available factors are not directly applied, as qualitative and quantitative mineralogy may differ among estuaries.

PCA also showed that the inorganic particles were among the main components of PC2, which brought about a variation of $25 \%$ in the estuary. The characteristics of suspended matter in this estuary appear to be influenced by anthropogenic sources and are dominated by organo-mineral aggregates. Such dominance of organo-mineral aggregates with variable amounts of inorganic fraction (mean $89 \%$ ) has been reported in the Scheldt estuary (Chen et al. 2005). In Mandovi, inorganic particles were dominant due to dilution of organic matter (Hopkinson et al. 1998). However, the possibility of these particles to be exclusively inorganic is remote, as mangrove litters are a source of particles in the $>3$ to $<220 \mu \mathrm{m}$ range in this estuary. Occurrences of higher numbers of inorganic particles associated with organic matter than the inorganic particles alone have been reported in estuaries like the Danube and San Francisco Bay (Hoch et al. 1995, Berger et al. 1996). On an annual basis, except for the months of March and August, organic carbon of the particles ranged from 2.6 to $7.8 \mathrm{mg} \mathrm{m}^{-2}$ with an overall high value during the SW monsoon season. This increased organic content of particles may be due to the shallow nature of the sampling site $(4 \mathrm{~m})$, leading to enrichment of organic matter from sediments via re-suspension by the tidal currents. Additional inputs from land runoff and riverine sources occur during this period. The abundance of PAB in the Mandovi estuary was 2 to 4 times more than that reported in temperate waters (Hoch et al. 1995, Berger et al. 1996) and the adjacent Zuari estuary (De Souza et al. 2003). However, it was lower than the highly organic rich Hudson and Indus River delta estuaries (Bano et al. 1997, Sanudo-Wil- helmy \& Taylor 1999). Although the quantitative POM content of the particles was low, its quality was high with a POC:PON ratio of 5.5 to 7.3. A ratio from 5 to 20 reflects that the particles contain decaying mangrove litter (Wafar et al. 1997). The low ratio could also be due to high value of nitrogen content in the particles from the large inputs of ammonium either from fertilizers (Sarma et al. 2001) or re-suspension of sediments (Sardessai \& Sundar 2007). The possibility of nutrients adsorbing to these inorganic particles cannot be eliminated (Holmboe \& Kristensen 2002). In the Mandovi, the residence time of water is about 5 to $6 \mathrm{~d}$ during the SW monsoon season (Qasim \& Wafar 1990). The degradation of organic matter will therefore be slow during the SW monsoon season due to relatively short residence time of resources. Thus, being enriched, these particles can serve as sites for bacterial colonization rather than degradation, especially during the SW monsoon season. In our study, PAB formed a high percentage of total bacteria, suggesting that the bacteria preferred these particles as a niche for colonization. The density of bacteria on particles could depend mainly on the organic content (quality) and the number of particles (quantity). PCA also supported the inference that the number of particles and their organic content could influence the variability of the estuary (Table 2).

PAB production was low in the Mandovi estuary. Various carbon conversion factors for BP have been reported for estuarine/coastal ecosystems because of intra- (20 to $77 \%$ ) and inter- (32 to $83 \%$ ) variability. Fukuda et al. (1998) concluded from their study that a factor of $30.2 \pm 12.3 \mathrm{fg} \mathrm{C} \mathrm{cell}^{-1}$ would be applicable for coastal bacterial assemblages. In a study on estuaries from Indian regions, Bhaskar \& Bhosle (2008) adopted $11 \mathrm{fg} \mathrm{C} \mathrm{Cell}^{-1}$, a value lower than that of the open ocean (Garrison et al. 2000), while Ram et al. (2007) used a conversion factor of $20 \mathrm{fg} \mathrm{C}$ cell $^{-1}$ based on Lee \& Fuhrman (1987). In our study, we used a carbon conversion factor of $20 \mathrm{fg} \mathrm{cell}^{-1}$, as its falls within the range of 12.3 to $30.2 \mathrm{fg} \mathrm{C}$ cell $^{-1}$ given by Fukuda et al. (1998) and enables comparison of our values to similar studies in Indian estuaries. The contribution by PABP to the TBP was $35 \%$, which was low when compared to that of $60 \%$ in the Zuari estuary (De Souza et al. 2003) in spite of the PAB abundance being in the same range between $10^{9}$ and $10^{10} \mathrm{l}^{-1}$. PAB production was also low when compared to reported values in the Loire estuary (803 $\mu \mathrm{g} \mathrm{l}^{-1} \mathrm{~d}^{-1}$ ) in France (Ducklow \& Shiah 1993) and tidal creeks of the Indus River delta (900 $\left.\mathrm{gg} \mathrm{l}^{-1} \mathrm{~d}^{-1}\right)$ in Pakistan (Bano et al. 1997). Earlier studies (Simon et al. 1990, Smith et al. 1992, Grossart \& Simon 1998) measured aggregate-associated bacterial production by pooling several aggregates. However, Ploug \& Grossart (1999) and Grossart \& Ploug (2000) showed 
high variability in production rates among aggregates of same and different sizes of particles due to a diffusion coefficient, as the exchange of solutes like radiotracers is reduced when aggregates are pooled and not in continuous suspension. In our study, although the aggregates were not pooled, the variability in number and weight per volume was low. It appears that the particles in the Mandovi estuary are relatively uniform in size and low in phytoplankton content as the chl a:POC ratio was low. Hence, the low POM and nature of the organic matter would have affected the growth rate (Murrell et al. 1999), which resulted in the low BP values observed in this estuary. The integrated PAB productivity was up to 1.8 times higher than that of PP. These values were higher than values reported for the temperate region (Williams 1981, Cole et al. 1988), but were closer to that reported for the Indus River delta (Bano et al. 1997).

Particles are known to be preferential sites for bacterial colonization (Grossart \& Ploug 2000). The cumulative carbon flux into bacteria, or bacterial carbon demand $(\mathrm{BCD})$ is the ratio of $\mathrm{BP}$ to the bacterial growth efficiency $(B G E)$. BGE $=B P /(B P+B R) \times 100)$, where $B P$ $=$ bacterial production and $\mathrm{BR}=$ bacterial respiration. Since PAB respiration was not measured in this study, the BGE value was obtained using 2 methods. In the first method, we used the equation of Grossart \& Ploug (2000), and in the second method we took the reported $\mathrm{BGE}$ values from the literature and used it for calculation of BCD.

Grossart \& Ploug's (2000) equation for BR is

$$
\mathrm{BR}=1.57 \times \mathrm{BP}^{0.86}
$$

The BR value was calculated to be 159, and accordingly, the BGE was estimated to be $57 \%$. The annual $\mathrm{BCD}$ for $\mathrm{PAB}$ was estimated to be $373 \mathrm{mg} \mathrm{C} \mathrm{m}$ (Table 3).

Very few studies are available on BGE of PAB (Ploug \& Grossart 1999, Grossart \& Ploug 2000). Ploug \& Grossart (1999) reported 0.35 $\pm 0.1 \mathrm{BGE}$ for aggregates of $>0.7 \mathrm{~mm}$. Grossart \& Ploug (2000) showed how BGE varied with the age of the aggregate from $0.45 \pm 0.04$ for 1 - to 3 -d-old aggregates to $0.23 \pm 0.06$ and $0.04 \pm$ 0.01 for 7 - and 14-d-old aggregates, respectively. Benner \& Hodson (1985) found lower BGE values of 5 to $20 \%$ for mangrove particulate detritus and 30\% for mangrove leachates in long-term incubations. This low BGE was presumably due to structural complexity of the detritus (Bano et al. 1997). All of these studies have shown the variability of BGE depending on the age of the aggregates and that the assumption that BGE increases with BP may not hold for estuaries with high allochthonous inputs from terrestrial sources. Thus, BGE of aggregates can range from 3 to $49 \%$ with an average of $24 \%$ (Grossart \& Ploug 2000). Further, the reported range of BGE of the total bacterioplankton in the Mandovi estuary was from 22 to $31 \%$ (Ram et al. 2007). As the Mandovi estuary has inputs from mangrove detritus and a significant amount of particles was inorganic, we assume that the growth efficiencies for $\mathrm{PAB}$ could be within a lower range. Generally, low $B G E$ values have been reported for mangrove detritus. Hence, based on the above rationale, we used an average value of $24 \%$ for calculating the $\mathrm{BCD}$ for $\mathrm{PAB}$. $\mathrm{BCD}$ for PAB was thus calculated to be $891 \mathrm{mg} \mathrm{C} \mathrm{m}^{-2}$ $\mathrm{d}^{-1}$, which is more than twice that calculated by using the equation. For estimating the total annual BCD of Mandovi, we used the published BGE value of $27 \%$ (Ram et al. 2007), and the calculated BCD was $2427 \mathrm{mg}$ $\mathrm{C} \mathrm{m}^{-2} \mathrm{~d}^{-1}$. This value is within the range for the Indus River delta reported by Bano et al. (1997). The calculated $\mathrm{BCD}$ for PAB ranged from 15 to $37 \%$ of the total BCD in the Mandovi estuary. The total BCD was 23 times more than the PP of carbon, which was much less than that reported for the Zuari estuary. Lignell (1990) observed that phytoplankton exudates in estuaries provide less than half the $\mathrm{BCD}$. $\mathrm{BCD}$ of $\mathrm{PAB}$ was 3.6 and 8.5 times higher than $\mathrm{PP}$, which means that 0.1 and $0.4 \%$ of PP was contributing to the BCD. Therefore, it is possible that the remaining BCD was from mangrove litter and other allochthonous sources. Since the BCD of PAB is high in the Mandovi, the turnover is faster on the particles compared to long turnover times of aggregates $>0.5 \mathrm{~mm}$ (Simon et al. 1990, Smith et al. 1992).

PCA showed that $47.9 \%$ of the variation in the estuary is governed by biotic variables. The number and nature of particles (PC3) increased the variability by $10.3 \%$. This suggests that apart from biotic parameters, the number and nature of particles also affect variation in the estuary. From the present study, it can be deduced that the flux of organic carbon in the mangrove-dominated Mandovi estuary is governed by $\mathrm{PAB}$, which in turn is dependent more on the input of quantity and quality of the particles from the adjacent mangroves and river run-off for preferential colonization than on phytoplankton carbon alone.

Table 3. Annual production of particle-associated bacteria (PABP), primary production (PP), and bacterial carbon demand (BCD). Values are depth integrated $\left(\mathrm{mg} \mathrm{C} \mathrm{m}^{-2} \mathrm{~d}^{-1}\right)$. See text for a description of the 2 methods used. TBCD: total bacterial carbon demand (2427 $\mathrm{mg} \mathrm{C} \mathrm{m}^{-2} \mathrm{~d}^{-1}$ ), BR: bacterial respiration, BGE: bacterial growth efficiency

\begin{tabular}{|cccccccc}
\hline Method & BR & PABP & $\begin{array}{c}\text { BGE } \\
(\%)\end{array}$ & BCD & PP & $\begin{array}{c}(\mathrm{PABCD} / \mathrm{TBCD}): P P \\
(\%)\end{array}$ \\
\hline 1 & 159 & 214 & 57 & 373 & 105 & 0.15 \\
2 & - & 214 & 24 & 891 & 105 & 0.35 \\
\hline
\end{tabular}


Acknowledgements. This work was sponsored by the Office of Naval Research, Washington, USA. We thank the anonymous referees for their valuable suggestions, which contributed to the improvement of the manuscript. We also thank C.T. Achuthankutty for reviewing this manuscript and for his valuable comments. This is NIO contribution no. 4563.

\section{LITERATURE CITED}

Bano N, Nisa MU, Khan N, Saleem M, Harrison PJ, Ahmed SI, Azam F (1997) Significance of bacteria in the flux of organic matter in the tidal creeks of the mangrove ecosystem of the Indus River delta, Pakistan. Mar Ecol Prog Ser 157:1-12

Barille-Boyer AL, Barille L, Masse H, Razet D, Heral M (2003) Correction for particulate organic matter as estimated by loss on ignition in estuarine ecosystems. Estuar Coast Shelf Sci 58:147-153

Benner R, Hodson RE (1985) Microbial degradation of the leachable and lignocellulosic components of leaves and wood from Rhizophora mangle in a tropical mangrove swamp. Mar Ecol Prog Ser 23:221-230

Berger B, Hoch B, Kavka G, Herndl GJ (1996) Bacterial colonization of suspended solids in the River Danube. Aquat Microb Ecol 10:37-44

Bhaskar PV, Bhosle NB (2008) Bacterial production, glucosidase activity and particle-associated carbohydrates in Dona Paula bay, west coast of India. Estuar Coast Shelf Sci 80:413-424

> Chen MS, Wartel S, Eck BV, Maldegem DV (2005) Suspended matter in the Scheldt estuary. Hydrobiologia 540:79-104

Clarke KR, Warwick RM (1994) Change in marine communities: an approach to statistical analysis and interpretation. Plymouth Marine Laboratory, Plymouth

Cole JJ, Findlay S, Pace ML (1988) Bacterial production in fresh and saltwater ecosystems: a cross-system overview. Mar Ecol Prog Ser 43:1-10

> Crump BC, Baross JA (2000) Characterization of the bacterially-active particle fraction in the Columbia River estuary. Mar Ecol Prog Ser 206:13-22

Crump BC, Baross JA, Simenstad CA (1998) Dominance of particle-attached bacteria in the Columbia River estuary, USA. Aquat Microb Ecol 14:7-18

> De Souza MJBD, Nair S, Loka Bharathi PA, Chandramohan D (2003) Particle-associated bacterial dynamics in a tropical tidal plain (Zuari estuary, India). Aquat Microb Ecol 33: $29-40$

Ducklow HW, Shiah FK (1993) Bacterial production in estuaries. In: Ford TG (ed) Aquatic microbiology: an ecological approach. Blackwell Scientific Publications, Boston, MA, p 261-287

Fuhrman JA, Azam F (1982) Thymidine incorporation as a measure of heterotrophic bacterioplankton production in marine surface waters: evaluation and field results. Mar Biol 66:109-120

> Fukuda R, Ogawa H, Nagata T, Koike I (1998) Direct determination of carbon and nitrogen contents of natural bacterial assemblages in marine environments. Appl Environ Microbiol 64:3352-3358

Garrison DL, Gowing MM, Hughes MP, Campbell L and others (2000) Microbial food web structure in the Arabian sea: a US JGOFS study. Deep-Sea Res II 47:1387-1422

> Gorsky G, Picheral M, Stemmann L (2000) Use of the underwater video profiler for the study of aggregate dynamics in the north Mediterranean. Estuar Coast Shelf Sci 50: $121-128$
Grossart HP, Ploug H (2000) Bacterial production and growth efficiencies: direct measurements on riverine aggregates. Limnol Oceanogr 45:436-445

> Grossart HP, Simon M (1998) Bacterial colonization and microbial decomposition of limnetic organic aggregates (lake snow). Aquat Microb Ecol 15:127-140

Hedges JI, Stern JH (1984) Carbon and nitrogen determinations of carbonate-containing solids. Limnol Oceanogr 29: $657-663$

- Heiri O, Lotter AF, Lemcke G (2001) Loss on ignition as a method for estimating organic and carbonate content in sediments: reproducibility and comparability of results. J Paleolimnol 25:101-110

> Hobbie JE, Daley RJ, Jasper S (1977) Use of Nucleopore filters for counting bacteria by fluorescence microscopy. Appl Environ Microbiol 33:1225-1228

Hoch BM, Berger B, Kavka G, Herndl GJ (1995) Remineralization of organic matter and degradation of the organic fraction of suspended solids in the River Danube. Aquat Microb Ecol 9:279-288

Holmboe N, Kristensen E (2002) Ammonium adsorption in sediments of tropical mangrove forest (Thailand) and a temperate Wadden Sea area (Denmark). Wetl Ecol Manag 10:453-460

> Hopkinson CS, Buffam I, Hobbie J, Vallino J and others (1998) Terrestrial inputs of organic matter to coastal ecosystems: an intercomparison of chemical characteristics and bioavailability. Biogeochemistry 43:211-234

Hubertz ET, Cahoon LB (1999) Short-term variability of water quality parameters in two shallow estuaries of North Carolina. Estuar Coasts 22:814-823

> Iriberri J, Unanue M, Ayo B, Barcina I, Egea L (1990) Bacterial production and growth rate estimation from $\left[{ }^{3} \mathrm{H}\right]$ Thymidine incorporation for attached and free-living bacteria in aquatic systems. Appl Environ Microbiol 56:483-487

Krey I (1964) Die mittlere Tiefenverteilung von Seston Mikrobiomasse und Detritus im nördlichen Nordatlantik. Kieler Meeresforsch 20:18-29

> Lee S, Fuhrman JA (1987) Relationships between biovolume and biomass of naturally derived marine bacterioplankton. Appl Environ Microbiol 53:1298-1303

Lee C, Wakeham S (1988) Organic matter in seawater: biogeochemical processes In: Riley JP (ed) Chemical oceanography, Vol 9. Academic Press, New York, p 1-51

> Lignell R (1990) Excretion of organic carbon by phytoplankton: its relation to algal biomass, primary productivity and bacterial secondary productivity in the Baltic Sea. Mar Ecol Prog Ser 68:85-99

Lohrenz SE, Knauer GA, Asper VL, Tuel M, Michaels AF, Knap AH (1992) Seasonal variability in primary production and particle flux in the northwestern Sargasso Sea: U.S. JGOFS Bermuda Atlantic Time-Series Study. DeepSea Res 39:1373-1391

Mesquita AM, Kaisary S (2007) Distribution of iron and manganese. In: Shetye SR, Kumar MD, Shankar D (eds) The Mandovi and Zuari estuaries. Research Publishing Services, Chennai, p 99-104

Murrell MC, Hollibaugh JT, Silver MW, Wong PS (1999) Bacterioplankton dynamics in northern San Francisco Bay: role of particle association and seasonal freshwater flow. Limnol Oceanogr 44:295-308

Parsons TR, Maita Y, Lalli CM (1984) A manual of chemical and biological methods for seawater analysis. Pergamon, Oxford

Ploug H, Grossart HP (1999) Bacterial production and respiration in suspended aggregates - a matter of the incubation method. Aquat Microb Ecol 20:21-29 
Qasim SZ, Wafar MVM (1990) Marine resources in the tropics. Resour Manag Optimization 7:141-169

Ram ASP, Nair S, Chandramohan D (2003) Bacterial growth efficiency in the tropical estuarine and coastal waters of Goa, Southwest coast of India. Microb Ecol 45:88-96

Ram ASP, Nair S, Chandramohan D (2007) Bacterial growth efficiency in a tropical estuary: seasonal variability subsidized by allochthonous carbon. Microb Ecol 53: 591-599

Revilla M, Iriarte A, Madariaga I, Orive E (2000) Bacterial and phytoplankton dynamics along a trophic gradient in a shallow temperate estuary. Estuar Coast Shelf Sci 50: 297-313

Russell MJ, Montagna PA (2007) Spatial and temporal variability and drivers of net ecosystem metabolism in Western Gulf of Mexico estuaries. Estuar Coasts 30:137-153

Russell MJ, Montagna PA, Kalke RD (2006) The effect of freshwater inflow on net ecosystem metabolism in Lavaca Bay, Texas. Estuar Coast Shelf Sci 68:231-244

Sanudo-Wilhelmy SA, Taylor GT (1999) Bacterioplankton dynamics and organic carbon partitioning in the lower Hudson River estuary. Mar Ecol Prog Ser 182:17-27

Sardessai S, Sundar D (2007) Variability of nitrate and phosphate. In: Shetye SR, Kumar MD, Shankar D (eds) The Mandovi and Zuari estuaries. Research Publishing Services, Chennai, p 59-66

Sarma VVSS, Dileep Kumar M, Manerikar M (2001) Emission

Editorial responsibility: Lars Tranvik,

Uppsala, Sweden of carbon dioxide from a tropical estuarine system, Goa, India. Geophys Res Lett 28:1239-1242

Schlesinger WH (1997) Biogeochemistry: an analysis of global change, 2nd edn. Academic Press, San Diego, CA

Shetye SR, Gouveia AD, Singbal SY, Naik CG, Sundar D, Michael GS, Nampoothiri G (1995) Propagation of tides in the Mandovi-Zuari estuarine network. J Earth Syst Sci 104:667-682

Shetye SR, Michael GS, Vishwas CP (2007) Mixing and intrusion of salt. In: Shetye SR, Kumar MD, Shankar D (eds) The Mandovi and Zuari estuaries. Research Publishing Services, Chennai, p 49-58

Simon M, Alldredge AL, Azam F (1990) Bacterial carbon dynamics on marine snow. Mar Ecol Prog Ser 65:205-211

Smith DC, Simon M, Alldredge AL, Azam F (1992) Intense hydrolytic enzyme activity on marine aggregates and implications for rapid particle dissolution. Nature 359: 139-142

UNESCO (1994) Protocols for the Joint Global Ocean Flux Study (JGOFS) core measurements. IOC manual and guides 29, UNESCO, Paris

- Wafar S, Untawale AG, Wafar MVM (1997) Litter fall and energy flux in a mangrove ecosystem. Estuar Coast Shelf Sci 44:111-124

Williams PJL (1981) Incorporation of microheterotrophic processes into the classical paradigm of the planktonic food web. Kieler Meeresforsch 5:1-28

Submitted: April 30, 2008; Accepted: June 15, 2009 Proofs received from author(s): September 22, 2009 